likely to be fully understood. The unanswered questions are of fundamental biochemical and physiological interest and it is hoped that their solution will not be long delayed.

\title{
REFERENCES
}

Abels, J., Nieweg, H. O. \& Schipperijn, A. J. M. (1964). Lancet i, 271.

Abels, J., Woldring, M. G., Vegter, J. J. M. \& Nieweg, H. O. (1957). Science, N.Y. 126, 558.

Baker, S. J., Mackinnon, N. L. \& Vasudevia, P. (1958). Indian Y. med. Res. 46, 812.

Berk, L., Castle, W. B., Welch, A. D., Heinle, R. W., Anker, R. \& Epstein, M. (1948). New Engl. F. Med. 239, 9 I I.

Bird, O. D. \& Hoevet, B. (195I). F. biol. Chem. rgo, I8I.

Blackburn, E. K., Spray, G. H., Swan, H. T., Tudhope, G. R. \& Wilson, G. M. (1959). Br. med. \%. ii, 535 .

Booth, C. C., Chanarin, I., Anderson, B. B. \& Mollin, D. L. (1957). Br. F. Haemat. 3, 253.

Booth, C. C. \& Mollin, D. I. (1957). Lancet ii, 1007.

Booth, C. C. \& Mollin, D. L. (1959). Lancet i, 18.

Castle, W. B. (1929). Am. F. med. Sci. 178, 748.

Castle, W. B. \& Townsend, W. C. (1929). Am. F. med. Sci. 178, 764.

Castle, W. B., Townsend, W. C. \& Heath, C. W. (1930). Am. F. med. Sci. 180, 305.

Chalmers, J. N. M. \& Shinton, N. K. (1958). Lancet ii, 1298.

Conley, C. L. \& Krevans, J. R. (1955). Ann. intern. Med. 43, $75^{8}$.

Cooke, W. T., Cox, E. V., Meynell, M. J. \& Gaddie, R. (1957). Lancet ii, 123 I.

Donaldson, R. M. Jr (I 964). Gastroenterolgy 46, 609.

Doscherholmen, A. \& Hagen, P. S. (1957). F. clin. Invest. 36, 155 I.

Glass, G. B. J. (1955). Revue Hémat. 10, I37.

Glass, G. B. J. (1963). Physiol. Rev. 43, 529.

Glass, G. B. J. (1964). Adv. clin. Chem. 7, 235.

Heinle, R. W., Welch, A. D., Scharf, V., Meacham, G. C. \& Prusoff, W. H. (1952). Trans. Ass. Am. Physns 65, 214.

Herbert, V. (1965). Gastroenterology 49, 218.

Holdsworth, E. S. \& Coates, M. E. (196r). Clin. chim. Acta 6, 44.

Minot, G. R. \& Murphy, W. P. (1926). F. Am. med. Ass. $87,470$.

Moertel, C. G., Scudamore, H. H., Owen, C. A. \& Bollman, J. L. (r960). Am. F. Physiol. 199, 289.

Mooney, F. S. \& Heathcote, J. G. (I966). Br. med.f. i, i I49.

Nyberg, W. \& Reizenstein, P. (I958). Lancet ii, 832.

Okuda, K. \& Sasayama, K. (1965). Proc. Soc. exp. Biol. med. 120, I7.

Reizenstein, P. G. (1959). Acta med. scand. 165, 481.

Reynell, P. C., Spray, G. H. \& Taylor, K. B. (1957). Clin. Sci. 16, 663.

Simnet, K. I. \& Spray, G. H. (I965). Br. F. Nutr. I9, 593.

Smith, A. D. M. \& Ellis, H. (1965). Lancet ii, 1277.

Taylor, K. B. (1963). Gastroenterology 45, 670 .

Taylor, K. B., Mallett, B. J., Witts, L. J. \& Taylor, W. H. (1958). Br. F. Haemat. 4, 63.

Wolff, R., Nabet, P., Jamaigne, M. C. \& Bertheau, M. F. (1966). Lancet i, 93.

\section{Iron absorption}

\author{
By Sheila T. Callender, Nuffield Department of Clinical Medicine, \\ Radcliffe Infirmary, Oxford
}

We do not yet know how iron traverses the mucosal cell of the intestine. Granick's ingenious theory of the mechanism of control of iron absorption through the ferritinapoferritin system of the mucosal cell was founded on very few experiments and there has since accumulated abundant evidence that 'mucosal' block if it does occur is a relatively inefficient factor in regulating iron absorption. 
One only has to take, for example, the findings of Smith \& Pannacciulli (I958) which show that the greater the dose of iron the more is absorbed although the percentage of absorption falls. Furthermore, when one abstracts the information collected by Josephs (I958) for chemical iron balance studies the same overall conclusion is reached, i.e. the greater the amount of iron in the diet the more is absorbed.

It is, however, also true that the greater the need for iron the more will be absorbed and there are undoubtedly factors which can alter the absorption of iron in relation to iron requirements. It has been shown repeatedly that subjects with iron-deficiency anaemia usually show augmented iron absorption. Thus in our studies using a standard dose of $5 \mathrm{mg}$ iron as ferrous sulphate, non-anaemic controls absorbed $8-70 \%$ of the dose with a mean of $30 \%$, while subjects with iron deficiency absorbed I $4-94 \%$ with a mean of $56 \%$. This same difference between non-anaemic and iron-deficient subjects is also shown in studies using labelled haemoglobin as the source of iron. Thus absorption of a dose of haemoglobin adjusted to contain $5 \mathrm{mg}$ iron was $\mathrm{I}-32 \%$ in non-anaemic controls with a mean of $\mathrm{I} 3 \%$, and $\mathrm{I}-68 \%$ in iron-deficient subjects with a mean of $25 \%$.

Although in general subjects with iron deficiency absorb more iron from a standard dose than normal individuals and those with increased iron stores less, there are notable exceptions to this rule. Patients with idiopathic steatorrhoea cannot absorb iron even though they may be grossly iron-deficient. Conversely patients with some forms of iron overload, for example primary haemochromatosis, continue to absorb iron even though they have no need of it (vide infra).

Investigation of such pathological states in which the normal regulatory mechanism has failed might be expected to give some clues as to the factors which control iron absorption.

It came as a surprise to many to find that iron from haemoglobin could be absorbed, since for many years it was supposed that such iron was not available for absorption. It is a convenient form of food iron to study since it can be easily labelled with radioactive iron and the dose given can be readily adjusted to contain $5 \mathrm{mg}$ iron to make it directly comparable with the test dose of inorganic iron which is commonly used.

Comparison with other forms of labelled food such as eggs, spinach, and liver is difficult as the total content of iron of these foods is variable. Some workers have tried to get round this by adding a tracer quantity of inorganic iron to a standard meal containing 4-5 mg iron but it is not certain that the iron in the meal can be regarded as being uniformly labelled.

Absorption from one form of food iron may differ greatly from that from others, as is well illustrated by considering the difference in absorption of inorganic and haemoglobin iron. To begin with, they are absorbed at different rates-the peak of the radio-iron absorption curve after a dose of haemoglobin is some 100-109 min after ingestion, as compared with 60-90 min after inorganic iron in normal subjects. Subjects with iron deficiency show a similar difference although the peaks appear earlier.

Absorption of inorganic iron is greatly affected by other constituents of the diet. For example, phytates and phosphates which precipitate the iron as an insoluble salt, 
reduce absorption, but they have no such effect on absorption of haemoglobin iron (Turnbull, Cleton \& Finch, I962).

Recently there has been renewed attention to the role of gastric secretions in the absorption of iron. Here again there is a difference between studies using inorganic iron and haemoglobin iron. Thus we were unable to show any reduction in absorption of haemoglobin iron in subjects with achlorhydria, nor were we able to increase absorption by the addition of $100 \mathrm{ml}$ of normal human gastric juice of $\mathrm{pH}_{2}$ (Biggs, Bannerman \& Callender, r96I).

Jacobs, Bothwell \& Charlton (1964) have even suggested that the absorption of haemoglobin iron may be depressed by the addition of acid. On the other hand, these authors have shown that the addition of hydrochloric acid enhances absorption of both ferrous and ferric iron salts and Goldberg, Lockhead \& Dagg (1963), using a standard meal to which a tracer amount of iron had been added, have shown reduced absorption in a group with achlorhydria as compared with a group with normal acid.

Koepke \& Stewart $\left(\mathrm{Ig}_{4}\right)$ have recently suggested that there is a factor in gastric juice which binds iron and which may be compared in action to the intrinsic factor which binds vitamin $B_{12}$. They found that iron given with gastric juice from anaemic dogs was better absorbed than when given with juice from control dogs. They also thought that they had in vitro evidence that the factor responsible was probably muco- or glyco-protein in nature and was more abundant in the gastric juice of anaemic dogs. Eric Ezekiel (personal communication) has been unable to confirm this in in vivo studies in rats but the original findings certainly warrant further investigation.

The other intestinal secretion which appears to be related to iron absorption is the exocrine secretion of the pancreas. Experimental work as long ago as 1935 (Taylor, Stiven \& Reid, 1935) indicated that pancreatic damage was associated with iron overload, and it has recently been shown that subjects with severe and chronic pancreatitis have increased iron absorption (Davis \& Badenoch, 1962). Since then other clinical conditions which may be associated with pancreatic damage have been investigated.

It has been noted that children with untreated fibrocystic disease of the pancreas usually have a high haemoglobin value and that they may develop iron-deficiency anaemia on treatment with pancreatin (Smith, 1964). Studies with radioactive iron in such children have shown a striking increase in iron absorption in untreated cases (Tönz, Weiss, Strahm \& Rossi, I965) but reduced iron absorption on treatment with pancreatin (Smith, I964).

A reduction of iron absorption has also been noted in primary haemachromatosis when the test dose is given with pancreatin. That this is evident not only when the iron is given as an inorganic iron salt (Biggs \& Davis, I963) but also as labelled haemoglobin (Callender, 1965) suggests that the effect of the pancreatin is not simply due to bicarbonate rendering the iron insoluble but rather that there is a specific inhibitor to iron absorption in pancreatic extracts.

Another condition in which iron overload may occur is cirrhosis of the liver. This 
disease is furthermore often associated with chronic pancreatic damage. It is therefore interesting to find that patients with cirrhosis often have markedly increased iron absorption and that this can be reduced towards normal on giving the test dose with pancreatin (Callender, 1965 ).

In an attempt to elucidate further the part played by the pancreas in iron absorption, Helen Brown (unpublished), in our laboratory, produced pancreatic damage with ethionine in rats on a restricted protein intake. She investigated the absorption in two groups of rats, one given an iron supplement and one iron-deficient. These groups were further subdivided into those with and those without pancreatic damage. Iron absorption in the rats with the iron supplement was increased in those with pancreatic damage and addition of pancreatin restored absorption to normal, but in the iron-deficient rats the findings were reversed, i.e., pancreatic damage was accompanied by diminished iron absorption which was restored to control values by the addition of pancreatin. These contradictory findings emphasize the complexity of the problems of iron absorption.

In these few remarks I have only touched on some of the factors which affect iron absorption. Iron deficiency remains one of the world's greatest nutritional problems and until we learn a great deal more about the complex mechanisms and interactions of the many factors concerned in the control of iron absorption, it is likely to remain with us.

\section{REFERENCES}

Biggs, J. C., Bannerman, R. M. \& Callender, S. T. (1961). Proc. Congr. Europ. Soc. Haematol. virI. Basle.

Biggs, J. C. \& Davis, A. E. (1963). Lancet ii, 814 .

Callender, S. (1965). Publs R. Coll. Physns Edinb. no. 30, p. 84.

Davis, A. \& Badenoch, J. (1962). Lancet ii, 6.

Goldberg, A., Lockhead, A. C. \& Dagg, J. H. (1963). Lancet i, 848.

Jacobs, P., Bothwell, T. \& Charlton, R. W. (1964). F. appl. Physiol. r9, I87.

Josephs, H. W. (1958). Blood 13, 1.

Koepke, J. A. \& Stewart, W. B. (1964). Proc. Soc. exp. Biol. Med. 115, 927.

Smith, M. D. \& Pannacciulli, I. M. (1958). Br. \%. Haemat. 4, 428.

Smith, R. S. (1964). Br. med. F. i, 608 .

Taylor, J., Stiven, D. \& Reid, E. W. (1935). F. Path. Bact. 41, 397.

Tönz, O., Weiss, S., Strahm, H. W. \& Rossi, E. (1965). Lancet ii, 1096.

Turnbull, A., Cleton, F. \& Finch, C. A. (1962). f. clin. Invest. 41, 1897.

\section{Some aspects of the absorption and concentration of iodide by the alimentary tract in man}

By W. D. Alexander, R. McG. Harden, M. T. Harrison and J. Shimmins, Department of Medicine, Gardiner Institute, Western Infirmary, Glasgow, $W_{\mathrm{I}}$

Iodine is absorbed in some parts of the alimentary tract, and in other parts it is secreted into the lumen of the gut (Brown-Grant, I961). Inorganic iodine is concentrated from the plasma by the stomach and the salivary glands and then secreted into the gastric juice and saliva. It is completely absorbed in the intestine so 